\title{
The Correlation Between the Perception of Parental Discipline Towards Students Independence at Muhammadiyah University Of Education Sorong
}

\author{
$1^{\text {st }}$ Syams Kusumaningrum ${ }^{1}$ \\ \{syams.bing@gmail.com ${ }^{1}$ \} \\ Universitas Pendidikan Muhammadiyah Sorong, West Papua, Indonesia
}

\begin{abstract}
This research tried to identify the correlation between gender-oriented parenting towards students independence at Muhammadiyah University of Education-Sorong. In collecting the data this research used psychological scale. The scale of gender-oriented parenting was designed related to five aspects, such as; authority and decision-making process, division of parenting duties, nurturing technical treatment, students' score, and also parents' hope about their children's future. According to Douvan, the scale of genderoriented parenting was made based on the three aspects, such as the independency in emotions, behavior and values. This research was conducted at Muhammadiyah University of Education-Sorong's students. The population in this research was 180 female students, aged around 17-22 years old and had siblings (male). As the sample this research take 123 female students by using simple random technique sampling. The result of regression analysis showed that rxy $=0,419$ with $p=0,000(p<0,05)$. The score of rxy demonstrated the positive correlation between the two variables. So, the higher gender-oriented parenting would show the higher independency of the female students and also the lower genderoriented parenting could present the lower independency of the female students. The gender-oriented parenting contributed $17,5 \%$ towards students' independency at Muhammadiyah University of Education-Sorong. So, there was $82,5 \%$ from other factors that influence students' independency such as education, intelligence, personality, environment, friendship and culture. The gender-oriented parenting with the empirical mean $=146$ was being at the high level. It was similar with the students' independency that had empirical mean $=96,943$.
\end{abstract}

Kata Kunci: Gender-Oriented Parenting, Independence

\section{Background}

Gradually, humans began to change the patterns of behavior that they exhibit as children, from being completely dependent to being more independent and independent individuals. The drive to become a more independent human being is a natural urge that is increasingly pressing to be fulfilled when an individual enters adolescence.

The above statement is in line with the statement of Covey (1997, pp. 38-40) that the individual starts his life with the nature of dependence, then gradually leads to independence, until when the individual is more mature, the individual reaches interdependence.

According to Covey, independence is not the highest achievement, because interdependence is a much more mature concept. However, independence itself is a major 
achievement, because interdependence is a choice that can only be made by individuals who are capable of being independent.

According to Havighurst (quoted by Monks, 2002, p.24), being independent is one of the developmental tasks of adolescence. Achievement of each developmental task is something important because the success of carrying out developmental tasks according to Hurlock (2000, p.40) will lead to happiness and success in carrying out other tasks later. College students are the largest and promising market segment for the beauty industry. According to Hardy (1998, p.126) the beauty industry succeeded in instilling beauty myths in women, such as that women who are loved by many people are beautiful women who are thin, tall, fair-skinned, and have straight hair. This can be seen from the many young women who are trying to change themselves like the standards created and standardized by the beauty industry. Students do it with the aim that they get the attention and recognition of the people around them. Efforts to become a center of interest are carried out even without regard to the actual potential they have or "who" themselves, such as doing various ways so that their skin looks white, their bodies look slim and also sexy, or wearing clothes that ultimately actually make them looks "strange" and seems forced.

The student's behavior is a manifestation of their independence. The independence is seen in the inability of female students to resist external influences so that they lose control of themselves and they are controlled by things other than themselves. Students treat the body or themselves more as objects to be observed and evaluated than as part of the wholeness of an autonomous subject. Covey (1997, p. 39) states, when a feeling of worth and comfort for oneself is obtained by the individual from the opinions of others about himself, the condition indicates individual independence.

According to Hardy (1998, p.129), when external influences are felt to be getting stronger but they fail to meet these standards, then young women become someone who lacks selfconfidence. The loss or lack of confidence in one's own potential ultimately inhibits and damages the self-actualization of female college students. The implication is that although the opportunities available for female students to actualize themselves in various fields are increasingly open, they tend to hesitate to take the opportunity.

Based on an initial survey conducted by researchers of 50 female students at Muhammadiyah University of Education-Sorong with simple questions about whether they plan to continue their careers out of town or abroad, around 70\% of them answered "no" or "don't know" with the most reason being fear of staying away from parents and it's up to parents' decisions. The survey shows that there is still a phenomenon of independence in these students. Not being independent makes them unable to take advantage of the opportunities they get, to the maximum extent possible.

Based on this, independence is not something that is not important for women. Hardy (1998, p.140) emphasized the importance of having independence for women, through independence they can determine their own attitudes on various issues related to women's needs and can further highlight the other side of their humanity, for example abilities and skills. Steinberg (2002, p.288) emphasized that in adolescence, autonomy cannot be equated with freedom. According to him freedom is the ability of individuals to behave according to their own while independence has more complex components such as emotions, cognitive and behavior, but the growth of freedom is part of achieving independence during adolescence.

Nuryoto (1993, p.49) in his research stated that individuals who have strong independence will be able to be responsible, dare to face problems and risks, and not easily influenced or dependent on others. According to Mussen, et al (1994, p.496-497) without a proper level of independence and separation from parents, adolescents will be difficult to expect to achieve peer 
relationships or mature sexual relationships, vocational guidance or understanding of identity, all of which require image about yourself as a unique, consistent and well-integrated person.

Independence is not a skill that emerges suddenly, but must be nurtured and learned in one's life (Dhamayanti, 2006, p.18). In the process of learning that is needed the role of the family so that children can experience changes from circumstances that are entirely dependent on parents to be independent. Children are trained to be independent from the beginning of childhood, but according to Wall (in Dhamayanti, 2006, p.18) new independence will be fully achieved by the end of adolescence.

In the family it is the parents who play a role in nurturing, guiding and helping direct the child to become independent. The important role of parents in independence is also stated by Mussen (1994, p.497-498), according to him parents play an important role in determining how well a teenager will be able to meet the demands for increased autonomy and become competent, confident adults with self-image positive. A number of researchers have studied the relationship between parenting parents with adolescent independence. One of them is research I Nyoman Karma (2002, p.45), whose research results show that parenting both authoritarian and permissive parents inhibits the development of mid-adolescent autonomy and authoritative parenting patterns support the development of mid-adolescent autonomy.

For young women, in this case female students themselves, independence is not an easily achieved developmental task, they are faced with various obstacles. As Murniati's statement (2004, p.102), according to her, it is very difficult for women to become independent individuals because society always connects women with dependency. Gender bias is one of the fundamental factors that inhibits women from achieving independence. Gender bias in question is the views and attitudes that prioritize one sex than the other sex as a result of the regulation and cultural beliefs that are more pro-gender (Ministry of Women's Empowerment, 2006). Culture or ideology that exaggerates biological differences between men and women according to Millet (in Ihromi, 1995, p.97-98) such culture or ideology is called patriarchy.

Patriarchal culture has also influenced the parenting of their children. Such parenting is called parenting that is gender biased or not gender oriented. Parenting is not gender-oriented in research Anggriany and Astuti (2003, p.44) are defined as parenting based on gender values which tend to create injustice so that it inhibits women from accessing, participating and mastering various things, this parenting tends to confuse the notion of sex or sex with gender. Gender-oriented parenting is a parenting that provides more opportunities for access, participation and mastery of men and women, both parents and children, to various matters equally.

Students who are nurtured in patriarchal culture will tend to wear the values of society and have less opportunity to develop their personal values. In such circumstances, women or in this study are young women who will feel helpless, inclined to submit and depend themselves on the authority holders which is the same as failure to achieve independence. Parents who have a more gender-just ideology will be manifested in a pattern of caring for their children who are more gender-oriented. The parents will treat the child based on their interests and abilities or potentials, no longer on the basis of gender alone or stereotyped role type, then the treatment seems to be able to empower female students as early as possible. Students will be better able to make decisions on their own. The dependency that has been "attached" to the female student is not natural, because being dependent or being independent is the result of the process of learning and training during the development mass

Based on the background associated with the phenomenon of the still presence of young women at Muhammadiyah University of Education-Sorong who have not been able to take advantage of various opportunities because of their independence, the researchers intend to 
obtain empirical results regarding whether there is a relationship between gender-oriented parenting practices with independence in young women.

\section{Literature Reviewed}

According to Dowling (1995, p.89), independence arises from learning that a person can achieve or do something himself, can control his own abilities, and can trust self-assessment. According to Schaefer (1996, p.173), independence or standing on one's own feet can be defined as the desire to control and control one's own actions and to be free from outside control. Another definition of independence was expressed by Chaplin (2000, p.48), according to him independence is a state of self-regulation or individual freedom to choose, to become a unit that can govern, control and determine themselves.

Kartono, et al $(2000, p .40)$ state that independence is a healthy feeling about competence, freedom and self-confidence, which is produced through a trajectory that successfully passes the levels of personality development at an individual's young age. Drost (1993, p.17), defines independence more broadly but simply, namely a state of perfection and wholeness of the two elements namely mind and body in a personal unity, and according to him an independent person is someone who understands who and what he is himself. The achievement of independence seems more evident when individuals enter adolescence. According to Steinberg (2002, p.288), in adolescence forming or achieving independence is an important part of becoming an adult besides the formation of self-identity. In addition, according to him being independent is one of the fundamental developmental tasks in adolescence.

According to Soetjiningsih (2004, p.47), the development of independence in adolescents follows three stages of development in adolescence, namely in early, middle, and late adolescence. Independence in adolescence is not only interpreted as freedom to do something yourself. According to Steinberg (2002, p. 288), autonomy or independence and independence or freedom, are interpreted differently. According to him freedom is the ability of individuals to behave according to their own while independence has more complex components such as emotions, cognitive and behavior, but the growth of freedom is part of achieving independence during adolescence.

During adolescence the demand for independence is indeed very large and if it is not responded to appropriately it can have adverse effects on the psychological development of adolescents in the future. The demand to be independent tries to be fulfilled by every individual throughout his life span. As a person ages, usually his level of independence will also increase. The development of independence starts from childhood, but independence begins to be achieved when the individual enters adolescence and is only fully achieved at the end of adolescence.

Young women achieve independence through their distinctive and quite different ways from men. Young women and men are treated differently during their development. According to Monks (2002, p. 277-278) it happened because of the interaction between the characteristics of women and the values of the surrounding community, so they experienced a personal dilemma. The dilemma arises because on the one hand the personal encouragement of rebellious adolescent girls wants to show their identity, because indeed they have something that is not inferior to men. On the other hand, the community, including the family, still ties it with the view of gender. Different treatment experienced by young men, parents are more likely to let them go. The independence achieved by young men or women will ultimately be different. 
The family has a very important role in efforts to develop a child's personality, because the family is the place for the first time a child gets an education and knows the values and regulations that must be followed, and also underlies the child to make social relations with the wider environment.

The pattern of care that is instilled in each family is different from other families, this depends on the views held by parents. The different views arise because of differences in culture, background, experience, education and the interests of parents, the diversity of parenting patterns is formed. When a child is born, there will always be gender classification based on his physical or biological condition. The classification will continue until each sex is associated with the characteristics of the nature and behavior that seems to be obeyed by each of these sexes, or commonly referred to as gender roles.

Santrock stated (2003, p.365) that gender roles are a set of expectations that determine how women and men should think, behave and feel. Something of concern is that the formation of gender roles by society is based on or influenced by patriarchal culture.

According to Murniati (2004, p.132), patriarchal insights require a change towards gender insights, which is a view that respects the views of women more, just and peaceful conditions are determined together, not only by the ruling group. So, gender-oriented parenting is a way how parents nurture and educate children in a fair and peaceful atmosphere that is determined together. The issue of gender ideology concerns gender differences, gender roles, and the division of labor within the family which results in gender injustice. Theories about genderoriented parenting basically have the same substance as the formation of the role of androgin types. Bem (quoted Gerungan, 2002, p.205) in his theory of sex roles, classified the role of masculine, feminine, androgin, and not classified. According to Santrock (2003, p. 381) states that androgyny is a type of role that is characterized by the high presence of masculine and feminine characteristics that are desired in individuals simultaneously.

Based on the explanation of the Ministry of Women's Empowerment, what is meant by access is the opportunity to use important resources, and participation is the involvement of a person in activities that are expected and important to him. While what is meant by fair and proportional is about gender justice, gender justice is a fair process for women and men, where justice does not focus on equal treatment but is more concerned with equality as a result. Gender equality itself means that men and women have the same conditions to use their rights and abilities to fully contribute to the development of themselves and the environment.

Based on the definitions stated by some of the figures above, it can be concluded that gender-oriented parenting is a way for parents to treat their children based on gender values that provide more opportunities for men and women to be able to use important resources and to engage in the desired activities, by emphasizing that men and women have different needs and powers, but parents create the same conditions for them to use their rights and abilities optimally.

\section{Hypothesis}

The hypothesis in this research was the gender-oriented parenting that had positive correlation towards the independence of the female students. The higher gender-oriented parenting would show the higher independence of the female students. On the other hand, the lower gender-oriented parenting would be followed by the lower independence of female students. 


\section{Research Method}

This research was quantitative by using psychological scale that took female students (around 17-22 years old) from Muhammadiyah University of Education-Sorong as the population. The population should have siblings (male) and parents. This research used simple random sampling to take the sample. Based on Krecjie table, there was 123 female students who has taken as the sample from 180 population.

This scale tried to measure the level of independence from the female students. This scale was arranged from the independence aspects that related to Douvan. Independence scale consist of 60 items that include 30 favorable items and 30 unfavorable items. Each item contains of 4 choices such as SS (totally appropriate), S (appropriate), TS ( inappropriate) STS (totally inappropriate). The score was 4 until 1 for the favorable item and 1 until 4 for the unfavorable item.

The purpose of the parenting scale was to know the level pattern of gender-orienting parenting that had been received from the female students. The scale was created based on the gender-oriented parenting that had been told by Anggriany and Astuti.

\section{Result and Discussion}

Through simple regression analysis techniques, it can be seen whether there is a relationship between gender-oriented parenting and independence in young women, as well as knowing how much the role of gender-oriented parenting as an independent variable, to independence in adolescent girls as dependent variables (Winarsunu, 2000, p. 98). All data analysis techniques in this study use the Statistical Package for Social Science (SPSS) 13.0 for Windows computer program.

The different power test is known through the calculation of Pearson product moment correlation coefficient and the reliability of the measuring instrument is known through the Cronbach alpha formula, both of which are calculated with the help of the SPSS computer program version 13.0, while the validity of the scale is done by justifying the validity of the appearance and content.

The results of the trial calculation on a scale of independence consisting of 60 items are 32 valid items and 28 deciduous items. Criteria for selection of items, based on the total item total correlation coefficient of 0.25 . The different power index items ranged from 0.253 to 0.502 with a reliability coefficient of 0.860 . Based on this, the researcher considers that the scale of independence in adolescent girls is quite feasible to be used in research.

The results of the trial calculation on a gender-oriented parenting scale consisting of 60 items are 45 valid items and 15 deciduous items. Criteria for selection of items, based on the total item total correlation coefficient of 0.25 . The total item power index is between 0.255 to 0.643 with a reliability coefficient of 0.920 . Based on this, the researcher considers that the scale of independence in female students is quite feasible to be used in research.

The normality test is carried out on the variables of caring pattern of gender and independence in young women using Kolmogrov Smirnov technique. Based on the normality test of gender-oriented parenting patterns, the significance value of Kolmogrov Smirnov was 
0.660 with a value of $p=0.777(p>0.05)$. These results indicate that the distribution of genderoriented parenting data has a normal distribution. Normality test for independence in young women obtained a significance value of Kolmogrov Smirnov of 0.641 with a value of $p=0.806$ $(p>0.05)$. These results indicate that the distribution of independence data on female students has a normal distribution.

The results of the linearity test with the coefficient values $F=25,697$ and $p=0,000$ ( $p$ $<0.05$ ), indicate that the relationship between the two research variables is linear. Linear results show that regression techniques can be used. Hypothesis testing in this study uses simple regression analysis. The regression equation for the relationship between the two variables is $\mathrm{Y}$ $=61.728+0.241 \mathrm{X}$. The correlation coefficient between gender-oriented parenting patterns with independence in female students is 0.419 with $p=0.000(p<0.05)$. The value of the positive correlation coefficient shows that the direction of the relationship between the two variables is positive, meaning that the higher the gender-oriented parenting pattern, the higher the independence of the female students, and vice versa. The results of a simple regression analysis show that the hypothesis proposed by the researcher is acceptable. The result of simple regression analysis is also to find out how much the contribution of the independent variable to the dependent variable. The coefficient of determination (r) of 0.175 means that gender-oriented parenting gives an effective contribution of $17.5 \%$ to the independence of female students.

Independence variable on female students with empirical mean of 96.943 and empirical standard deviation of 7.121 shows that the level of independence is in the high category with a range of values between 92 to 116. Empirical mean of gender-oriented parenting variables in this study is 146 with empirical standard deviation of 12,357 . The gender-minded parenting subject of the study is in the high category with a range of values between 129,375 to 163,125 .

The results of this study are in accordance with the hypothesis proposed that there is a positive relationship between gender-oriented parenting with independence in female students at Muhammadiyah University of Education-Sorong. The relationship between the two significant variables can be seen from the correlation coefficient of 0.419 with a significance level of correlation of $p=0,000(p<0.05)$. A positive sign on the correlation coefficient number indicates the direction of the relationship, a positive relationship indicates that the higher the gender-oriented parenting pattern, the higher the independence of the female student, and vice versa.

The results of the research prove that one of the factors that influences the independence of female students is gender-oriented parenting. The results of this study support Anggriany's (2003, p.49) research which shows how much influence parenting gender-oriented parenting has on the growth and development of psychological dependence or fear of independence in women, so they do not have the courage to make full use of brain power and creativity.

Parents form independence through caregiving since childhood. Anto (1998, p. 5) reinforces this by stating that the key to the success of education in the family lies in the correct use of parenting. The role of parents is very important in the formation of gender roles, if parents emphasize gender-oriented parenting, where men and women are given the opportunity to participate and master things fairly, then young women will be formed who are accustomed to not being dependent on parents. Gender-oriented parenting can be shown by parents in various aspects of parenting that show equality and fairness then it will form a process of generalizing children about the role of sex and relationships between men and women who are egalitarian. According to Uyun (2002, p. 5) through gender-oriented parenting, a feminine and masculine trait can be developed in a balanced manner that is beneficial for optimal personality development, and independence including. 
Gender-oriented parenting effective contribution of $17.5 \%$ to the independence of female students at Muhammadiyah University of Education-Sorong. The low level of effective contribution of gender-oriented parenting shows that gender-oriented parenting is just one of many factors that can influence independence in adolescent girls, in this case female college students. Other factors that influence independence according to Nuryoto (1993, p. 54) are education, intelligence, personality, living environment. According to Yusuf (2001, pp.81-129), one's peer and cultural influence on independence.

The level of gender-oriented parenting received by Muhammadiyah University of Education-Sorong students from his parents is in the high category. The high level of genderoriented parenting may be due to several things. One of them is the influence of education level in gender-oriented parenting, this is confirmed by the results of Anto's research $(1998, \mathrm{p} .8)$ which shows that education has a contribution in shaping one's gender insight, especially in parenting.

The mass media may also be an external factor that makes the high level of gender-oriented parenting. The values that are "carried" by various mass media change old ideologies such as patriarchy, into new ideologies that are more gender just. The ideology is likely to influence the adoption patterns, so the level of gender-oriented parenting practices is higher. In addition, the mass media also shows that currently the opportunity for women to be successful in public spaces is quite wide open, this condition is likely to give their parents hope. There is hope that parents may provide equal opportunities and support for the potential development of their children.

The level of independence of female students at Muhammadiyah University of EducationSorong is in the high category, with an empirical average value of 96.94, higher than the hypothetical average which has a score of 80 . The results of this study are somewhat different from the results of the initial survey which concluded that there was still no independence in the students at Muhammadiyah University of Education-Sorong. The female students still allow themselves to be guided by parents, and receive instructions from parents. This kind of attitude is also reinforced by the view of the community who agree that such an attitude is a form of obedience of a child to parents, especially for girls. Based on this, subject responses such as "no", "don't know", and "up to the parents" in the initial survey, do not fully indicate independence but rather the form of their obedience to parents.

Muhammadiyah University of Education-Sorong students have a high degree of independence that removes the stereotype that women should look dependent or not independent. The educational environment may have an influence on the high level of independence of its students. Muhammadiyah University of Education-Sorong as one of the good universities in Sorong has a variety of activities that are able to provide various insights and stimulate female students to develop their potential and talents optimally. A high level of independence in Sorong Muhammadiyah University of Education-Sorong students, may also be caused by female students in their late teens. In their late teens they are more faced with situations that begin to demand to be resolved by themselves and have a greater impact on their future, these conditions make young women try to be independent in order to solve everything and what they want to achieve.

This research did not escape the constraints and limitations. The limitation in this study is the limited time, because of the busyness in the University of Muhammadiyah Sorong Education University, so that data collection and research must be done in between their busy lives. These conditions make the survey less detailed, which results in making backgrounds that are less able to describe the reality or facts. In addition, researchers also paid less attention to the influence of cultural factors during the initial survey, so the results were somewhat different from the 
results of the research conducted. Based on the description above, it can be concluded that gender-oriented parenting has an influence on independence of female students at Sorong Muhammadiyah Education University. The high level of gender-oriented parenting shows that female students are cared for and educated by promoting equality between men and women. Students are given the same responsibilities and opportunities to determine something and develop their potential, so that students are able to do something for themselves without having to always depend on parents or other adults.

\section{Conclusion and Suggestion}

\subsection{Conclusion}

The results of the research obtained indicate that there is a positive relationship between gender-oriented parenting with independence in female students at Muhammadiyah University of Education-Sorong. A positive relationship indicates that the higher the gender-oriented parenting approach, the higher the independence of the female students. The effective contribution of gender-oriented parenting to independence in female students is $17.5 \%$, and others come from other factors, such as peer influence, intelligence, neighborhood and personality.

\subsection{Suggestion}

In order to contribute ideas, the following things can be suggested.

a) For research subjects, it is expected to maintain their already high independence. Students continue to improve their gender perspectives, so they are not trapped in stereotypes of roles that are not gender equitable. With that, all students are expected to position themselves as free but responsible individuals, able to develop their potential optimally, and dare to take various opportunities that are useful for self-development.

b) Further researchers who are interested in the same topic, can further enrich this research by paying attention to other factors that influence independence in female students.

\section{References}

[1] Anggriany, N., dan Astuti, Y.D. 2003. Hubungan Antara Pola Asuh Berwawasan Jender dengan Cinderella Complex. Psikologika. Nomor 16, Tahun VIII. 41-51.

[2] Anto, M.B., Syamsudin, M., Hastuti, S. 1998. Dampak Pola Asuh Berwawasan Gender Trehadap Peranan Wanita. Laporan Penelitian. Yogyakarta: Lembaga Penelitian PSW UII.

[3] Bainar. 1998. Wacana Perempuan dalam Keindonesiaan dan Kemodernan. Jakarta: PT. Pustaka Cidesindo.

[4] Covey, S.R.1997. Tujuh Kebiasaan Manusia yang Sangat Efektif (edisi revisi). Jakarta: Binarupa Aksara.

[5] Dhamayanti, A.A, dan Yuniarti, K.W. 2006. Kemandirian Anak Usia 2,5-4 tahun Ditinjau dari Tipe Keluarga dan Tipe Prasekolah. Sosiosains. 19(1). 17-30.

[6] Hardy, G.M., Primarianti., Pratiwi, R., Nelwan, I. 1998. Perempuan dan Politik Tubuh Fantastis. Yogyakarta: Kanisius.

[7] Hurlock, E.B. 1997. Psikologi Perkembangan Suatu Pendekatan Sepanjang Rentang Kehidupan (edisi kelima. Alih bahasa:Istiwidayanti., Soedjarwo., Sijabat, R.M.) . Jakarta: Erlangga.

[8] 2000. Perkembangan Anak, Jilid 1 (Alih bahasa: Tjandrasa, M.M., dan Zarkasih, M.). Jakarta : Erlangga. 
[9] 2000. Perkembangan Anak, Jilid 2 (Alih bahasa: Tjandrasa, M.M.). Jakarta : Erlangga.

[10] Ihromi, T.O. 1995. Kajian Wanita dalam Pembangunan. Jakarta : Yayasan Obor Indonesia.

[11] Karma, I Nyoman. 2002. Hubungan Antara Pola Pengasuhan Orangtua dan Otonomi Remaja. Jurnal Psikologi Universitas Padjajaran, Vol.9, No.1, 45-59.

[12] Kementerian Pemberdayaan Perempuan. (2007, 3 April). Glossary. $\mathrm{http} / / /$ www.menegpp.go.id/menegpp.php?cat=fix\&id=glossary

[13] Monks, F.J., Knoers, A.M.P., dan Haditono, S.R. 2002. Psikologi Perkembangan : Pengantar dalam Berbagai Bagiannya. Yogyakarta : Gadjah Mada University Press.

[14] Murniati, A.N. 2004. Getar Gender : Perempuan Indonesia dalam Perspektif Sosial, Politik, Ekonomi, Hukum dan HAM (Buku Pertama). Magelang : Indonesiatera.

[15] 2004. Getar Gender : Perempuan Indonesia dalam Perspektif Agama, Budaya, dan Keluarga (Buku Kedua). Magelang : Indonesiatera.

[16] Mussen, P.H. 1994. Perkembangan dan Kepribadian Anak. Jakarta : Arcan.

[17] Nuryoto, S. 1993. Kemandirian Remaja Ditinjau dari Tahap Perkembangan, Jenis Kelamin, dan Peran Jenis. Jurnal Psikologi, No 2, 48-58.

[18] Scaefer, C. 1996. Cara Efektif Mendidik dan Mendisiplinkan Anak (Alih Bahasa:

[19] Turman Sirait). Jakarta : Mitra Utama.

[20] SMA 3 Semarang. (2007, 2 Oktober). Fasilitas SMA 3. http://www.sman3smg.sch.id/inner.php?page=fasilitas

[21] $\quad(2007,2$ Oktober). Sejarah SMA 3 http://www.sman3smg.sch.id/inner.php?page $=$ sejarah

[22] . (2007, 2 Oktober). Sekolah Nasional Bertaraf Internasional (SNBI). http://www.sman3smg.sch.id/inner.php?page=snbi

[23] Steinberg, L. 2002. Adolescence. New York : McGraw Hill Companies, Inc.

[24] Uyun, Q. 2002. Pola Asuh Berwawasan Gender yang Mampu Mencerdaskan Emosi Anak. Jurnal Penelitian. Yogyakarta: PSW UII

[25] Winarsunu, T. 2004. Statistika dalam Penelitian Psikologi dan Pendidikan. Malang: UMM Press.

[26] Yusuf, S. 2001. Psikologi Perkembangan Anak dan Remaja. Bandung: PT. Remaja Rosdakarya 